\title{
Unresectable Head and Neck Squamous Cell Carcinoma
}

National Cancer Institute

\section{Source}

National Cancer Institute. Unresectable Head and Neck Squamous Cell Carcinoma. NCI

Thesaurus. Code C136427.

A squamous cell carcinoma that arises from the head and neck region and is not amenable to surgical resection. 